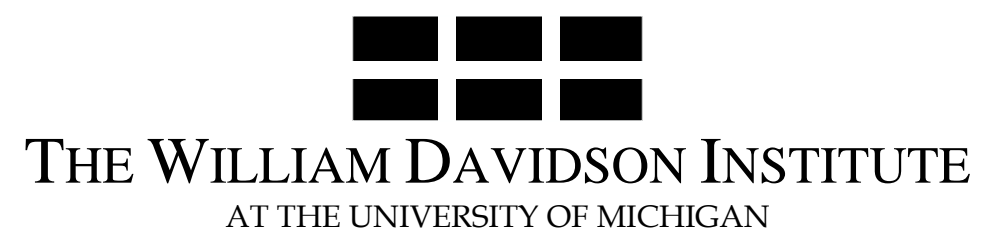

Financial Accelerator Effects in the Balance Sheets of Czech Firms

\author{
By: Roman Horváth
}

William Davidson Institute Working Paper Number 847

November 2006 


\title{
Financial Accelerator Effects in the Balance Sheets of Czech Firms
}

\author{
Roman Horváth* \\ Czech National Bank and Institute of Economic Studies, Charles University
}

\begin{abstract}
The paper examines a financial accelerator mechanism in analyzing determinants of corporate interest rates. Using a panel of the financial statements of 448 Czech firms from 1996-2002, we find that balance sheet indicators matter for the interest rates paid by firms. Market access is particularly important in this regard. The strength of corporate balance sheets seem to vary with firm size. There is also evidence that monetary policy has a stronger effect on smaller than on larger firms. On the other hand, we find no asymmetry in the monetary policy effects over the business cycle.
\end{abstract}

\section{JEL Classification: G11, G32}

Keywords: balance sheet channel, financial accelerator, interest rates, monetary policy transmission

* I thank Eva Horvathova for the data used in the paper and Martin Cincibuch for the helpful comments. The views expressed here do not necessarily represent those of the Czech National Bank.

Roman Horvath, Czech National Bank, Na Prikope 28, 11503 Prague 1, Czech Republic, Tel.: +420 22441 2925, fax: +420 224412329 E-mail: roman.horvath@.cnb.cz and roman.horvath@gmail.com 


\section{Introduction}

An accurate understanding of monetary policy transmission is key for efficient implementation of monetary policy. While there is considerable empirical evidence on the monetary policy transmission mechanism in the Euro area (see Angeloni, Kashyap, and Mojon 2003), there is a lack of knowledge about the transmission mechanism in the European Union's new member states, those acceding to the EU in 2004. This is striking for various reasons, especially considering that many of these economies are likely to join the Euro area in the very near future and thus be subject to common monetary policy. This paper aims to bridge this knowledge gap by providing empirical evidence on the balance sheet channel in one such new EU member, the Czech Republic.

Given the assumption of imperfect capital markets (in view of information asymmetries and/or contract enforcement problems), there is a wedge between the costs of internal and external financing. The balance sheet channel links the cost of external finance to the financial

position of the borrower. ${ }^{1}$ As a result, under contractionary shock, a firm's internal sources of funding typically worsen and the firm becomes more dependent on external finance. However, at the same time, the cost of external financing has a tendency to increase as the financial health of a borrower weakens. A greater dependence on external funding at a time when the cost of borrowing has increased has been characterized as a "financial accelerator effect” (Bernanke et al. 1999). In consequence, corporate financial positions-balance sheet strength—amplifies output fluctuations (Bernanke and Gertler 1989).

According to Gertler and Gilchrist (1993), monetary policy might have asymmetric effects

\footnotetext{
${ }^{1}$ Calstrom and Fuerst (1997), Kiyotaki and Moore (1997), and Bernanke et al. (1999) all model interactions between borrowing costs and the financial position of borrower.
} 
over the business cycle; that is, it is more powerful in downturns than in booms. ${ }^{2}$ In addition, Gertler and Gilchrist (1994) and Oliner and Rudebush (1996) suggest that monetary policy shocks have stronger effects on smaller firms than on larger firms as a result of unequal access to external financing. Boissay (2001) suggests that financial accelerator effects might be particularly strong during periods of credit rationing.

In this paper, we examine the aforementioned suppositions using a large dataset comprised of the financial statements of Czech firms from 1996 to 2002. We study if balance sheet position affects the interest rates firms are charged; we analyze the extent to which balance sheet positions are procyclical; and we investigate if monetary policy has heterogeneous effects, particularly as regards small firms and during periods of economic downturns.

As such, we seek to add to the existing evidence on corporate investment dynamics in the Czech Republic (Lizal and Svejnar 2002a, Lizal and Svejnar 2002b, Konings et al. 2003, Hanousek and Filler 2004). In general, these studies examine the role of ownership, credit rationing, and soft-budget constraints. While they provide important insights into the nature of Czech firms' investment dynamics, they typically employ data from the mid-1990s. More recently, Pruteanu (2004a) analyses whether banks credit rationed Czech enterprises during 1997-2002.

Typically, econometric studies investigating financial accelerator effects analyze corporate investment dynamics (see Vermeulen 2002 or Berg et al., 2004). Few studies have focused on

\footnotetext{
${ }^{2}$ See also Kashyap, Lamont, and Stein (1994). Another stream of literature highlights, toward obtaining the asymmetric effects of monetary policy, the role of downward price rigidity; see, for example, Ball and Mankiw (1994). Nevertheless, recent empirical evidence from Euro area countries tends to challenge the assumption of downward price rigidity (Dhyne et al. 2005).
} 
the determinants of corporate interest rates within the financial accelerator framework. Mojon, Smets, and Vermeulen (2002) inter alia analyze corporate interest rate dynamics in the four largest Euro-area countries in an error-correction context. They find that firm characteristics influence the interest rates firms are charged. In contrast to our results, they find little evidence that monetary policy in these countries has a heterogeneous impact on firms and/or over the business cycle. Benito and Whitley (2003) study the factors affecting corporate interest rates in the United Kingdom in a dynamic setting, and their results also indicate that firms' balance sheets are indeed an important determinant of corporate interest rates. In our paper, however, we apply a slightly different estimation strategy than these two studies.

In addition, we add to the scarce literature on monetary policy transmission in the Czech Republic. To our knowledge, this issue is studied systematically at the micro level only by Pruteanu (2004b) and Schmitz (2004). ${ }^{3}$ Pruteanu focuses on the bank lending channel. She finds that monetary policy affects the growth rate of loans more strongly in 1999-2001 than in 1996-98. In addition, there is certain evidence that monetary policy had heterogeneous effects on bank lending in 1999-2001. Similarly, Schmitz studies the role of banks in monetary policy transmission in several new EU members over the period 1990-2001, and while bank lending reacts significantly to monetary policy tightening, she finds no evidence of heterogeneity in monetary policy effects. ${ }^{4}$

The paper is organized as follows. Section 2 presents the description of our dataset as well as

\footnotetext{
${ }^{3}$ At the macro level, Arnostova and Hurnik (2005) study the monetary transmission mechanism in the Czech economy using vector autoregression analysis.

${ }^{4}$ However note that Schmitz's sample begins already in 1990. Interest rate ceilings were in use then, and vast majority of banks were still state owned.
} 
our estimation methodology. In Section 3, we present the descriptive statistics and regression analysis. We conclude in Section 4. Finally, Appendix offers detailed descriptions of the variables.

\section{Data and Methodology}

\subsection{Data}

The data employed for our aggregate level analysis are derived from the ARAD public database operated by the Czech National Bank (CNB). The data for the aggregate analysis includes debt outstanding and interest rates. Both variables are coded, according to their maturity, as short, medium, or long term (see Appendix for details). Primarily, we use this data to estimate a representative aggregate interest rate for a comparison with sample corporate interest rates.

Data for the corporate level analysis are obtained from company records compiled by the Čekia Agency, a Czech provider of business information services, as a part of their Magnus dataset. Originally, the unbalanced panel dataset incorporates the year-end financial statements of 461 non-financial companies from 1993 to 2002. Balance sheets and profit and loss accounts are available for each firm. The dataset also contains a detailed description of the economic activity of each firm. Using this information, we divide the companies into fifteen industries, as classified by the Czech Statistical Office: agriculture, food production, beverage and tobacco production, mining and processing of minerals and ors, textile and leather production, wood processing and paper production, chemical and pharmaceutics and rubber production, construction, metallurgy, machine building, electronics, power engineering, transportation, commerce, and glass and pottery. 
As a prelude to our estimation, we excluded firm records that appeared to contain inconsistencies. The first consistency check was simply to examine if the data takes on the expected values. For example, the value of a firm's assets should be positive. Analogously, the ratio of various items from the financial statements should exhibit the expected values. For instance, the ratio of liquid assets to assets or of debt to assets should lie between zero and one. On this basis, we excluded six firms from the sample.

Subsequently, there were only three firm records in the dataset available for 1993, two for 1994, and six for 1995. We therefore only used company records from the period 1996-2002. The majority of observations are from 1999-2002. While the dataset for 1996, 1997, and 1998 contain 17, 39, and 81 firms, respectively, the number of firms for 1999-2002 exceeds 300 . Namely, there are 309, 390, 362, and 305 firms for the years 1999, 2000, 2001, and 2002, respectively. In total, the unbalanced sample counts for 1494 observations from 448 firms. Typically, we are able to track at least three subsequent years of the records for a given firm.

\subsection{Estimation Methodology}

We first link the interest rate charged to balance sheet position, which is approximated by the extent of leverage, liquidity, market access, and collateral value. We also analyze whether small firms pay higher interest rates on average, and also if corporate interest rates increase during a downturn. Next, we examine if monetary policy has hetererogeneous effects on firms according to firm size. Finally, we investigate whether monetary policy affects corporate interest rates more strongly during a downturn. 
First, we estimate the equation (1) linking balance sheet indicators to corporate interest rates:

$$
I R_{i t}=\alpha_{1}+\alpha_{2} C O L L_{1, t} / A_{i, t}+\alpha_{3} D_{E B T_{i, t}} / A_{i, t}+\alpha_{4} C F_{i, t} / A_{i, t}+\alpha_{5} A_{C C E S S}+u_{i}+e_{i t}
$$

The dependent variable, $I R_{i t}$, represents the corporate interest rate paid by the $i$-th firm at time $t$, computed from the firm's financial statements (as the ratio of interest rate expenses to total debt). ${ }^{5}$ The variable $C O L L_{i t}$ stands for firm collateral. $D E B T_{i t}$ is the company net debt. The cash flow generated is $C F_{i t}{ }^{6}$ The variables $C O L L_{i t}, D E B T_{i t}$, and $C F_{i t}$ are normalized by $A_{i t}$, which is $i$-th firm assets at time $t$. The extent of short-term financing is captured by ACCESS $_{i t}$, which stands as the proxy for assessing the degree of market access of $i$-th firm at time $t$. This is calculated as one minus the ratio of short-term debt to total debt. Furthermore, $u_{i}$ is an unobserved firm fixed effect, and $e_{t t}$ is the error term. A detailed

\footnotetext{
${ }^{5}$ Benito and Whitley (2003) discuss the drawbacks this measure of corporate interest rates may eventually have. If a firm reduces the amount of its debt substantially in the course of a financial year, the resulting measure of corporate interest rates based on year-end balance sheets may be "artificially" high. To address the empirical relevance of this issue, we examine a correlation of our measure of interest rates and aggregate interest rates. In addition, we estimate the equations without outliers, excluding 5 percent of the lowest and highest interest rates (not reported). The empirical results suggest that this issue is only of limited relevance in our sample. The obvious advantage of using this measure of interest rates is that it provides large cross-sectional information, which is otherwise hardly available.
}

In addition, if firm does not rely on external financing, its interest rate expenses as well as our measure of corporate interest rates are zero. Note that there are only 6 such observations out of 1494 in our dataset.

${ }^{6}$ An alternative indicator of liquidity is the ratio of liquid assets to assets. In our sample, the correlation of liquid assets and cash flow (both normalized by assets) is 0.76 . In consequence, we do not report the results with liquid assets, as the results are qualitatively very similar. 
derivation of the variables is presented in Appendix.

The sign of $\alpha_{2}$ is expected to be negative. A firm with greater collateral value is likely to be charged a lower interest rate, as collateral secures debt (Kiyotaki and Moore 1997). Estimated $\alpha_{3}$ should yield a positive sign. More leveraged firms are in general more likely to default, and thus the lender seeks to be compensated by a higher interest rate. The sign of $\alpha_{4}$ should be negative, as more liquid firms are likely to be charged lower interest rates. Firms with better access to external funds are likely to encounter lower interest rates. The underlying supposition is that more risky firms are unable to receive long-term finance, and are thus forced to finance their projects with short-term debt (Bougheas et al. 2006). Thus, $\alpha_{5}$ is expected to be negative.

Additionally, we investigate if the interest rates charged are typically higher for small firms and/or during economic downturns. For convenience, balance sheet indicators $\left(C O L L_{i t} / A_{i t}\right.$, $D E B T_{i t} / A_{i t}, C F_{i t} / A_{i t}$ and $\left.A C C E S S_{i t}\right)$ are labeled as $X_{i t}$ thereafter.

In addition to Equation (1), we include two dummy variables in Equation (2):

$$
I R_{i t}=\beta_{1}+\beta_{2} X_{i, t}+\beta_{3} R E C E S S I O N+\beta_{4} S_{i}+u_{i}+e_{i t} .
$$

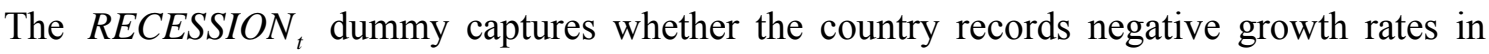
time $t$. The variable $S_{i}$ is a dummy to assess whether small firms typically encounter higher interest rates. 
We expect $\beta_{3}$ to be positive for several reasons. Banks may, for example, contract their lending during a downturn. Similarly, $\beta_{4}$ is likely to be positive, because small firms are more risky and/or entail greater agency costs for borrowers (Bernanke and Gertler 1990).

Next, we examine whether there is heterogeneity in the effects of monetary policy. Following Mojon et al. (2002), we test for this in two steps. First, we estimate if the response to monetary policy effects varies with firm size. Second, we assess whether monetary policy is more powerful during a downturn as compared with an upturn. The following two equations capture it more formally:

$$
\begin{aligned}
& I R_{i t}=\chi_{1}+\chi_{i} X_{i, t}+\chi_{3} i_{t} * S_{i}+\chi_{4} i_{t} * M_{i}+\chi_{5} i_{t} * L_{i}+u_{i}+e_{i t} . \\
& I R_{i t}=\delta_{1}+\delta_{i} X_{i, t}+\delta_{3} i_{t} * R E C E S S I O N_{t}+\delta_{4} i_{t} * \text { BOOM }_{t}+u_{i}+e_{i t} .
\end{aligned}
$$

Equation (3a) links the corporate interest rates to a vector $X_{i t}$ of balance sheet indicators and three additional explanatory variables. These are $i_{t} * S_{i}, i_{t} * M_{i}$, and $i_{t} * L_{i}$. The variable $i_{t}$ is a yearly average of two-week repurchase rate (the policy rate of the CNB), $S_{i}, M_{i}$, and $L_{i}$ are dummy variables for small, medium, and large sized firms (according to assets), respectively. It is expected that $\chi_{3} \succ \chi_{4} \succ \chi_{5}$, that is, that monetary policy effects have the strongest effects on small firms, as compared with medium and large sized firms (Mojon et al. 2002). ${ }^{7}$

\footnotetext{
${ }^{7}$ It is noteworthy that piece-wise correlations of these three variables lie between -0.13 and -0.15 ; thus, the level of multicollinearity is likely to be very low. Analogously, multicollinearity is not likely to be an issue when estimating Equation (3b).
} 
Analogously, Equation (3b) captures the effect of the business cycle on corporate interest rates, controlling for balance sheet indicators. The dummy variable RECESSION $_{t}$ takes on a unit value if economic growth has been negative in a given year. Conversely, $B O O M_{t}$ denotes the dummy variable stating when economic growth has been positive. In our sample, the Czech Republic recorded negative year-on-year real gross-domestic-product (GDP) growth in 1997 and 1998 (-0.8 percent and -1 percent, respectively). It is further expected that $\delta_{3} \succ \delta_{4}$, that is, that monetary policy is more potent during downturn. As mentioned, a detailed derivation of all the variables is presented in Appendix.

Regarding our econometric strategy, we do not apply dynamic panel data estimators (which is typical for this stream of literature) for two reasons: First, if applied, the number of observations reduces to about one-third because the time dimension of our sample is rather short. Second, the lagged dependent variable was insignificant in all the specifications we estimated (not presented here). An additional issue is the eventual severe bias in the estimates when dynamic panel data estimators are applied to small samples. Nerlove (2002) emphasizes that the Arellano-Bond method is inappropriate when the time dimension of a panel is short. In consequence, the estimation of our equations is based on the static panel data models accounting for endogeneity of regressors. As the instruments, we use industry and time dummies. While industry dummies may capture different risks of industries, time dummies may reflect macroeconomic effects. ${ }^{8}$

\footnotetext{
${ }^{8}$ As an informal test of the relevance of instruments for endogenous explanatory variables, we ran the ,firststage" equations and examined the significance of instruments. In all cases, there were several instruments significant. The resulting R-squared varied substantially. It was about 0.1 for balance sheet indicators and between 0.2-0.9 for variables including the policy interest rate such as the product of policy rate and small firm dummy.
} 


\section{Empirical Results}

In this section, we investigate financial accelerator effects in the balance sheets of Czech firms. We first analyze the role of the balance sheet position in explaining corporate interest rates. Second, we examine if CNB monetary policy exhibited heterogeneous effects in the sample period; that is, if it had a stronger effect on small firms, and during downturn.

The adequacy of our measure of a sample corporate interest rate is examined in Chart 1 . We compare this interest rate with the aggregate interest rate. Aggregate interest rates are calculated as the weighted average of inter-bank interest rates according to their maturity (see Appendix for details on construction). The weights are determined by the amount of respective outstanding loans. The sample interest rates are well correlated with the aggregate interest rates; we believe our sample is likely to be representative.

\section{Chart 1. Interest Rates: Corporate and Aggregate Levels}

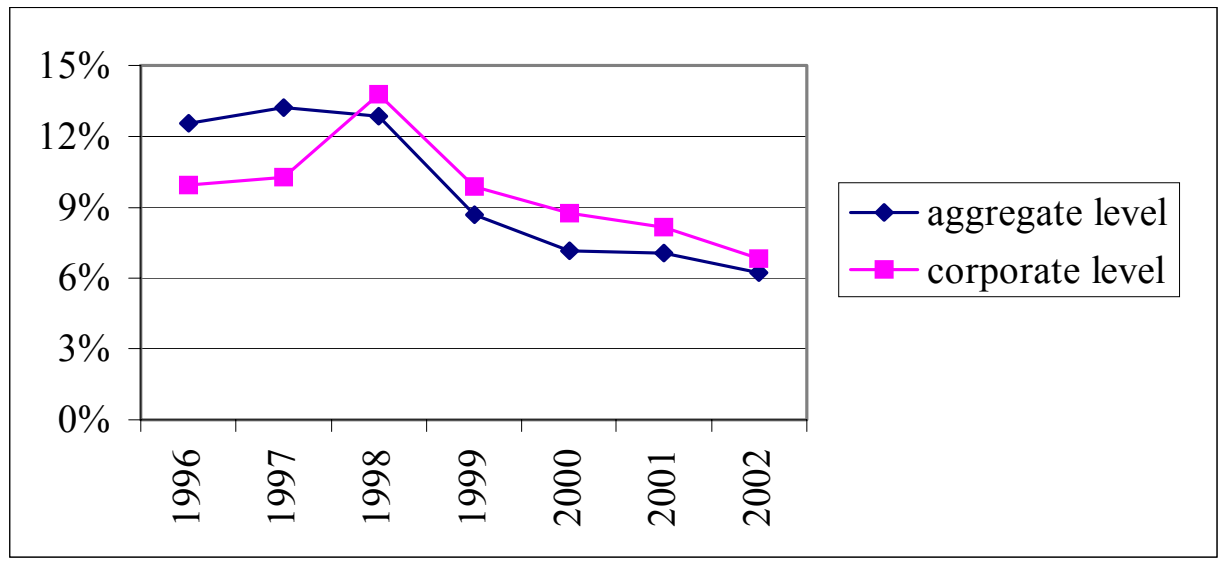

Chart 2 presents the distribution of corporate interest rates. It provides evidence of 
considerable firm heterogeneity concerning interest rates charged by banks. Besides, it seems the cross-sectional variation in interest rates depends on the mean corporate interest rate. When average rates are higher, the variation increases. This means that firm heterogeneity tends to increase during a downturn. Eventually, it suggests that credit conditions worsen more than proportionally for certain firms during downturns. For instance, the corporate interest rate at the $25^{\text {th }}$ percentile stands at around 7 percent and increases to 8 percent during the downturn, while the corresponding increase at the $75^{\text {th }}$ percentile is from 12 percent to 18 percent. Benito and Whitley (2003), using U.K. data, find a similar pattern.

\section{Chart 2. Distribution of Corporate Interest Rates}

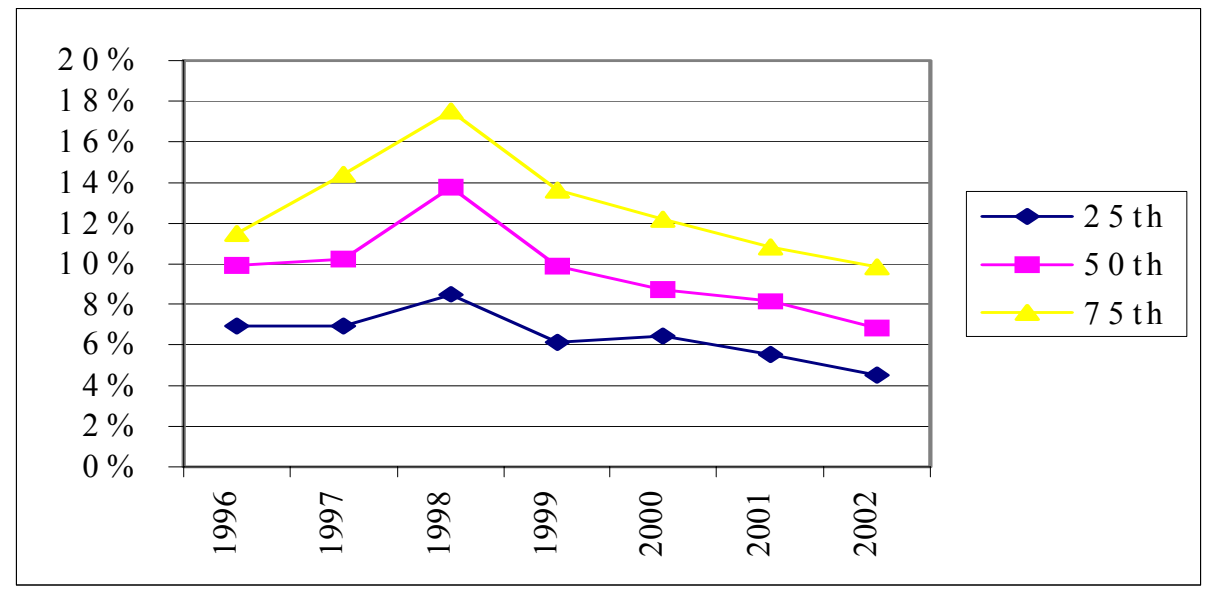

Note: The chart presents the $25^{\text {th }}, 50^{\text {th }}$, and $75^{\text {th }}$ percentiles of corporate interest rates over time.

Table 1 presents descriptive statistics on balance sheet indicators. Generally, the interest rates firms pay seem to be relative to firm size, despite the large standard errors. Rates are also higher in downturn, in contrast with boom. We seek to explicate this variation in interest rates in this paper, focusing specifically on the effects of monetary policy. Next, balance sheet indicators differ accross firm size as well. Interestingly, they seem to worsen only marginally during downturn. 
Table 1. Descriptive Statistics

\begin{tabular}{lcccccc}
\hline & $\begin{array}{c}\text { Small } \\
\text { firms }\end{array}$ & $\begin{array}{c}\text { Medium } \\
\text { firms }\end{array}$ & $\begin{array}{c}\text { Large } \\
\text { firms }\end{array}$ & Downturn & Boom & Total \\
& 12.04 & 9.67 & 8.86 & 12.88 & 10.02 & 10.25 \\
Interest rates & $(10.17)$ & $(7.05)$ & $(8.08)$ & $(7.76)$ & $(8.8)$ & $(8.75)$ \\
Net debt/Assets & 0.2 & 0.25 & 0.26 & 0.27 & 0.24 & 0.24 \\
& $(0.17)$ & $(0.21)$ & $(0.22)$ & $(0.16)$ & $(0.2)$ & $(0.2)$ \\
Market access & 0.22 & 0.27 & 0.32 & 0.28 & 0.27 & 0.27 \\
& $(0.23)$ & $(0.27)$ & $(0.29)$ & $(0.26)$ & $(0.27)$ & $(0.27)$ \\
Cash flow/Assets & 0.06 & 0.06 & 0.07 & 0.04 & 0.06 & 0.06 \\
& $(0.1)$ & $(0.14)$ & $(0.15)$ & $(0.09)$ & $(0.14)$ & $(0.13)$ \\
Collateral/Assets & 0.31 & 0.34 & 0.39 & 0.4 & 0.34 & 0.35 \\
& $(0.15)$ & $(0.16)$ & $(0.17)$ & $(0.18)$ & $(0.16)$ & $(0.16)$ \\
No. of observations & 493 & 493 & 506 & 120 & 1376 & 1494 \\
\hline
\end{tabular}

Note: See Appendix for details on construction of variables. Standard deviations in brackets.

\section{Chart 3. Internal Sources of Financing and Interest Rates}

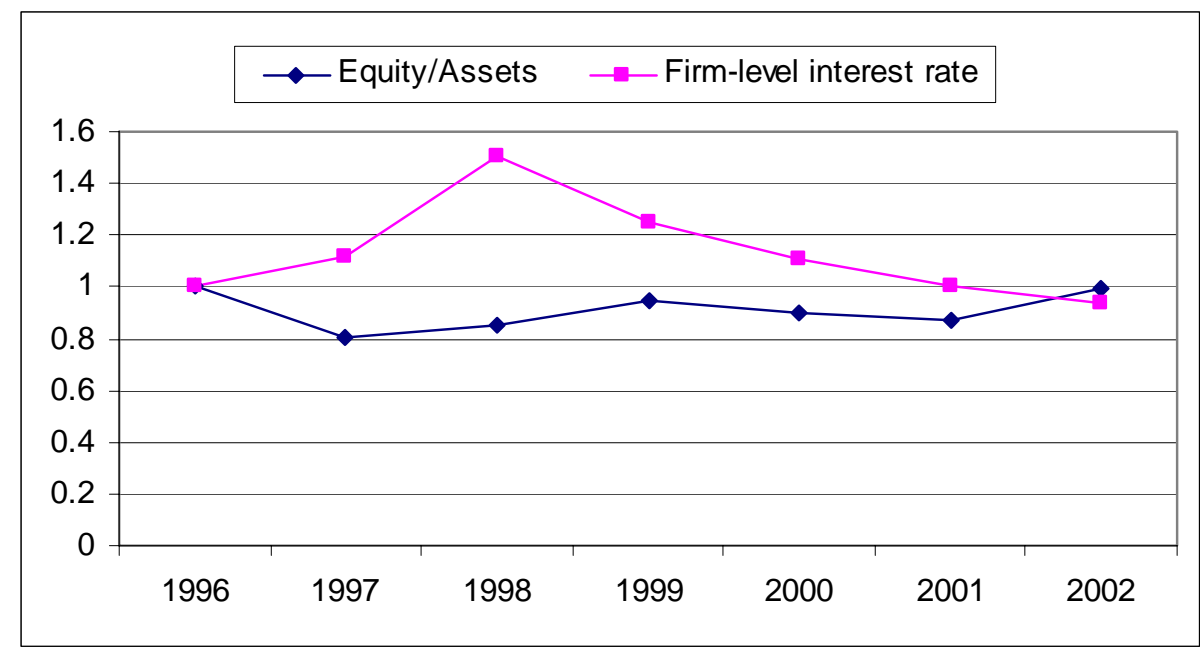

Chart 3 shows that when internal sources of financing deteriorate, credit conditions are likely to tighten. This suggests either the presence of the financial accelerator effect or simply the increase of firm's default risk when internal sources weaken. The ability of a firm to finance investment from internal sources is proxied by an equity-to-assets ratio. The credit conditions 
are assessed simply by the sample mean of the corporate interest rate.

Table 2. Determinants of Corporate Interest Rates

\begin{tabular}{|c|c|c|c|c|c|}
\hline & (1) & (2) & (3) & (4) & (5) \\
\hline Net Debt/Assets & $\begin{array}{c}4.99 * * \\
(2.15)\end{array}$ & $\begin{array}{c}2.13 \\
(2.78)\end{array}$ & $\begin{array}{c}3.98 * * \\
(2.11)\end{array}$ & $\begin{array}{l}3.98^{*} \\
(2.11)\end{array}$ & $\begin{array}{c}1.64 \\
(2.65)\end{array}$ \\
\hline Market access & $\begin{array}{l}-25.1 * * \\
(10.44)\end{array}$ & $\begin{array}{l}-21.5^{*} \\
(11.5)\end{array}$ & $\begin{array}{c}-26.54 * * * \\
(10.04)\end{array}$ & $\begin{array}{c}-26.54 * * * \\
(10.04)\end{array}$ & $\begin{array}{c}-23.35^{* *} \\
(10.88)\end{array}$ \\
\hline Cash flow/Assets & & $\begin{array}{c}-39.13 * \\
(20.9)\end{array}$ & & & $\begin{array}{l}-33.35^{*} \\
(20.02)\end{array}$ \\
\hline Downturn & & & $\begin{array}{l}2.21 * \\
(0.91)\end{array}$ & & $\begin{array}{l}1.98 * * \\
(0.99)\end{array}$ \\
\hline Small firms & & & & $\begin{array}{c}2.22 * * \\
(0.92)\end{array}$ & \\
\hline Fixed effects & $1.74 * * *$ & $1.36 * * *$ & $1.14 * * *$ & $1.86^{* * *}$ & $1.63 * * *$ \\
\hline R-sqr. overall & 0.01 & 0.02 & 0.01 & 0.01 & 0.02 \\
\hline No. of observations & 1494 & 1494 & 1494 & 1494 & 1494 \\
\hline & (6) & (7) & (8) & (9) & (10) \\
\hline Net Debt/Assets & & $\begin{array}{c}3.20 \\
(2.99)\end{array}$ & $\begin{array}{c}2.05 \\
(2.96)\end{array}$ & & \\
\hline Market access & $\begin{array}{c}-16.15^{*} \\
(9.54)\end{array}$ & $\begin{array}{l}-20.25^{*} \\
(11.15)\end{array}$ & $\begin{array}{c}-22.82 * * \\
(10.87)\end{array}$ & $\begin{array}{c}-12.71 * \\
(7.31)\end{array}$ & \\
\hline Cash flow/Assets & $\begin{array}{c}-52.85 * * * \\
(17.52)\end{array}$ & $\begin{array}{l}-28.17 \\
(24.16)\end{array}$ & $\begin{array}{l}-29.63 \\
(23.37)\end{array}$ & & \\
\hline Downturn & & & $\begin{array}{l}1.90^{*} \\
(1.02)\end{array}$ & $\begin{array}{c}2.35 * * * \\
(0.79)\end{array}$ & $\begin{array}{l}1.92 * * \\
(0.83)\end{array}$ \\
\hline Small firms & & $\begin{array}{c}8.24 \\
(9.99)\end{array}$ & $\begin{array}{c}2.98 \\
(10.06)\end{array}$ & $\begin{array}{c}6.95 \\
(5.50)\end{array}$ & $\begin{array}{l}10.72 * \\
(5.63)\end{array}$ \\
\hline Fixed effects & $1.45 * * *$ & $1.57 * * *$ & $1.65 * * *$ & $2.74 * * *$ & $2.48 * *$ \\
\hline R-sqr. overall & 0.02 & 0.03 & 0.08 & 0.02 & 0.01 \\
\hline No. of observations & 1494 & 1494 & 1494 & 1494 & 1494 \\
\hline
\end{tabular}

Notes: Asymptotic standard errors in parenthesis. Net debt and cash flow are divided by assets (see Section 2.2). $* * *, * *$, and $*$ - denotes significance at 1 percent, 5 percent, and 10 percent, respectively. See Appndix for the details on the construction of variables.

Next, we study how a firm's balance sheet position affects the level of interest rates the firm is charged. We present determinants of corporate interest rates in Table 2 (an estimation is 
carried out by the IV panel data fixed effects estimator). ${ }^{9}$ We report the results for ten various specifications together to give some insight into the sensitivity of the estimates. The results suggest that, of the balance sheet indicators, market access particularly matters. There is also certain evidence that leverage and liquidity influence corporate interest rates. Remarkably, collateral has been insignificant in all the specifications, which may reflect difficulties in terms of the relationship between economic performance and law enforcement during the sample period (see Roland and Verdier 2003). ${ }^{10}$

Table 2 also presents determinants of corporate interest rates, toward which we are particularly interested in the influence of economic downturn and firm size (i.e., small firms). The results indicate that Czech firms paid higher interest rates during economic downturn. Small firms seem to pay higher interest rates, since it is more difficult for lenders to monitor small entities. However, significant small firm and downturn variables do not necessarily imply financial accelerator effects. It may simply reflect the greater risk firms present during downturns or the greater risk inherent in small firms, respectively. For this reason, we investigate if monetary policy effects propagate more strongly to small firms (or during downturns), controlling for balance sheet indicators as a proxy for firm risk.

Table 3 documents the heterogeneous impact of monetary policy on firms. Generally, the explanatory variables are significant with the expected signs in all the specifications.

\footnotetext{
${ }^{9}$ In several specifications, the random-effects estimator was consistent, as indicated by a Hausman test. We do not report these results for the sake of brevity. We also re-estimated all the specifications bootstrapping standard errors. In the majority of the specifications, bootstrapped errors were close to asymptotic standard errors. The results are available on a request.

${ }^{10}$ The results with collateral as an explanatory variable are available on a request.
} 
Moreover, the value of coefficients is typically stable accross the specifications to a large extent. Controlling for the strength of balance sheet indicators, we find that small firms react more strongly to monetary policy effects, in comparison to medium and large sized firms. The coefficient on the product of repo (policy) rate and the small firm dummy is consistently the largest and most precisely estimated. Interestingly, we find weak evidence that monetary policy affects the interest rates large sized firms are charged. This may indicate that larger firms have closer ties with banks and that, therefore, monetary policy effects are likely to have less impact on them. Overall, our results correspond to Vermeulen (2002), who finds that financial accelerator effects are strongest for small firms' investment dynamics in a sample of the four largest Euro area countries. On the contrary, the result of Mojon, Smets, and Vermeulen (2002) do not suggest that monetary policy effects would be stronger for small firms' interest rates.

Table 3. Determinants of Corporate Interest Rates -

Firm Size, Downturns and Monetary Policy

\begin{tabular}{|c|c|c|c|c|c|}
\hline & 1 & 2 & 3 & 4 & 5 \\
\hline Net debt/Assets & & $\begin{array}{c}0.38 \\
(1.86)\end{array}$ & $\begin{array}{l}-0.62 \\
(2.06)\end{array}$ & & $\begin{array}{l}-2.87 \\
(1.87)\end{array}$ \\
\hline Market Access & & $\begin{array}{c}-17.02 * * \\
(8.73)\end{array}$ & $\begin{array}{c}-23.36^{* *} \\
(10)\end{array}$ & & $\begin{array}{c}-16.08 * * \\
(7.75)\end{array}$ \\
\hline Cash flow/Assets & & $\begin{array}{c}-9.37 \\
(16.73)\end{array}$ & $\begin{array}{c}-2.93 \\
(17.31)\end{array}$ & & $\begin{array}{c}-5.52 \\
(15.14)\end{array}$ \\
\hline Repo*Small firm & $\begin{array}{c}0.77 * * \\
(0.34)\end{array}$ & $\begin{array}{c}1.01 * * * \\
(0.27)\end{array}$ & $\begin{array}{c}0.90 * * \\
(0.37)\end{array}$ & & \\
\hline Repo*Medium firm & $\begin{array}{c}0.14 \\
(0.29)\end{array}$ & & $\begin{array}{l}-0.18 \\
(0.33)\end{array}$ & & \\
\hline Repo*Large firm & $\begin{array}{c}0.11 \\
(0.31)\end{array}$ & & $\begin{array}{c}0.61 \\
(0.44)\end{array}$ & & \\
\hline Repo*Recession & & & & $\begin{array}{c}0.29 * * * \\
(0.09)\end{array}$ & $\begin{array}{c}0.5 * * * \\
(0.12)\end{array}$ \\
\hline Repo*Boom & & & & $\begin{array}{c}0.36^{* *} \\
(0.17)\end{array}$ & $\begin{array}{c}0.75 * * * \\
(0.22)\end{array}$ \\
\hline Fixed effects & $2.52 * *$ & $2.33 * * *$ & $2.37 * * *$ & $2.64 * * *$ & $2.93 * * *$ \\
\hline R-sqr. overall & 0.03 & 0.07 & 0.08 & 0.02 & 0.12 \\
\hline No. of observations & 1494 & 1494 & 1494 & 1494 & 1494 \\
\hline
\end{tabular}

Note: For mnemonics, see Table 2. 
Table 3 also displays the results on the asymmetric effect of monetary policy over the business cycle. There are several studies investigating the potential asymmetry of monetary policy. Using Austrian data for the period 1976-98, Kaufmann (2002) finds that monetary policy effects are indeed asymmetric over the business cycle. Similarly, Peersman and Smets (2005) find the asymmetric impact of monetary policy on industrial production in the Euro area countries.

Contrary to expectations raised in the previous section, our results do not suggest that monetary policy is more potent during downturn. Rather it seems that monetary policy effects are actually stronger during the boom period, despite that the coefficients on $i_{t} *$ RECESSION ${ }_{t}$ and $i_{t} *$ BOOM $_{t}$ are not statistically different. In our opinion, the lack of the asymmetric effects of monetary policy may reflect the specificity of the Czech credit market during the 1990s. The market was marked by rather soft budget constraints at the outset of economic transition and subsequent credit rationing at the end of the 1990s (Hampl and Matousek 2000). ${ }^{11}$

\footnotetext{
${ }^{11}$ We also examine the heterogeneous impact of monetary policy depending on credit conditions. When credit conditions are tight, it is likely that small policy changes trigger a greater reaction in corporate interest rates than otherwise. We identify tight credit conditions using the results of Pruteanu (2004a). Pruteanu finds that the period 1999:1-2000:12 might be labeled as one of credit rationing, as her empirical results suggest that moderate excess demand for bank loans existed then. She argues that excess demand has been a consequence of the downturn in 1997-98 and of continuing instability in the banking sector. Following economic recovery, the demand for loans increased, though this was not followed by sufficient growth in the loan supply given the lack of improvement in issues related to very high level of bad loans in the Czech banking sector. Indeed, our results suggest that monetary policy has significantly stronger effects on corporate interest rates in 1999-2000. Nevertheless, these results hinges on identification of credit rationing by one particular paper and thus are not presented in the text. Nevertheless, they are available on a request. Next, we also investigated if the effect of
} 


\section{Conclusions}

In this paper, we examined the determinants of corporate interest rates using a panel dataset based on financial statements from Czech firms from the 1996-2002 period. Namely, we assessed the relationship between a firm's financial position and the cost of external financing. In addition, we examined if monetary policy has heterogeneous effects on firms according to their size and if the response to monetary policy effects is time-varying. Examining the heterogeneity of monetary policy effects allows us to assess the presence of financial accelerator effects in the Czech economy.

Overall, the results suggest that balance sheet indicators are a vital determinant of corporate interest rates. We find that, among balance sheet indicators, market access matter in particular (leverage and liquidity matter, to a certain extent, as well). In addition, the strength of balance sheet indicators is seem to vary with the firm size. We also find certain evidence of the heterogeneous impact of monetary policy effects. Monetary policy has stronger effects on small than on medium and large sized firms. Yet, we find no evidence that monetary policy effects depend on the business cycle.

To summarize, our results indicate that balance sheet indicators affect the interest rates firms are charged by borrowers, and that monetary policy effects propagate unequally across firms, suggesting some support for the existence of financial accelerator effects in our sample.

each of the characteristics of balance sheets on corporate interest rates is more important for small firms and during economic downturn, but failed to uncover any systematic differences. These results are also available on a request. 


\section{References}

Angeloni, I.; A. Kashyap; and B. Mojon. 2003. Monetary Policy Transmission in the Euro Area. Cambridge, UK: Cambridge University Press.

Arnostova, K., and J. Hurnik. 2005. The Monetary Transmission Mechanism in the Czech Republic: Evidence from VAR Analysis. Czech National Bank Working Paper Series, No. 4/2005. (available at www.cnb.cz).

Ball, L., and G. Mankiw. 1994. Asymmetric Price Adjustment and Economic Fluctuations. The Economic Journal 104, 247-61.

Benito, A., and J. Whitley. 2003. Implicit Interest Rates and Corporate Balance Sheets: An Analysis Using Aggregate and Disaggregated UK Data. Bank of England Working Paper No. 193 (available at www.bankofengland.uk).

Berg, C.; J. Hansen; and P. Sellin. 2004. The Financial Accelerator and Corporate Investment. Sveriges Riksbank Economic Review 2.

Bernanke, B.S., and M. Gertler. 1989. Agency Cost, Net Worth and Business Fluctuations. American Economic Review 79,14-31.

Bernanke, B.S.; M. Gertler; and S. Gilchrist. 1999. The Financial Accelerator in a Quantitative Business Cycle Framework. In Handbook of Macroeconomics, Volume 1, eds. J. Taylor and M. Woodford. Amsterdam: North Holland.

Boissay, F. 2001. Credit Rationing, Output Gap and Business Cycles.” European Central Bank Working Paper Series, No. 87 (available at www.ecb.int).

Bougheas, S; P. Mizen; and C. Yalcin. 2006. Access to External Finance: Theory and Evidence on the Impact of Firm-Specific Characteristics. Journal of Banking and Finance 30, 199-227.

Calstrom, C., and T. Fuerst. 1997. Agency Costs, Net Worth and Business Fluctuations: A Computable General Equilibrium Analysis. American Economic Review 87, 893-910.

Dhyne, E.; L. Alvarez; H. Le Bihan; G. Veronese; D. Dias; J. Hoffmann; N. Jonker; P. Lunnemann; F. Rumler; and J. Vilmunen. 2005. Price Setting in the Euro Area: Some Stylized Facts from Individual Consumer Data. European Central Bank Working Paper No. 524 (available at www.ecb.int).

Gertler, M., and S. Gilchrist. 1993. The Role of Credit Market Imperfections in the Monetary Transmission Mechanism: Arguments and Evidence. Scandinavian Journal of Economics 95, 43-64.

___ 1994. Monetary Policy, Business Cycles and the Behavior of Small 
Manufacturing Firms. The Quarterly Journal of Economics 109, 309-40.

Hanousek, J., and R. Filler. 2004. Investment, Credit Rationing, and the Soft Budget Constraint: What Would a Well-functioning Credit Market Look Like? Economics Letters 82, 385-90.

Hampl, M., and R. Matousek. 2000. Credit Contraction in the Czech Republic: The Causes and Consequences. Czech National Bank Working Paper Series, No.19 (available at www.cnb.cz).

Kashyap, A.; O. Lamont; and J. Stein. 1994. Credit Conditions and the Cyclical Behavior of Inventories. The Quarterly Journal of Economics 109, 565-92.

Kaufmann, S. 2002. Is There an Asymmetric Effect of Monetary Policy over Time? A Bayesian Analysis Using Austrian Data. Empirical Economics 27, 277-97.

Kiyotaki, N., and J. Moore. 1997. Credit Cycles. Journal of Political Economy 105, $211-48$.

Konings, J.; M. Rizov; and H. Vandenbusche. 2003. Investment and Financial Constraints in Transition Economies: Micro Evidence from Poland, the Czech Republic, Bulgaria and Romania. Economics Letters 78, 253-8.

Lizal, L. 1999. Depreciation Rates in Transition Economy: Evidence from Czech Panel Data. Prague Economic Papers, 8,261-76.

Lizal, L., and J. Svejnar. 2002a. Investment, Credit Rationing and the Soft Budget Constraint: Evidence from Czech Panel Data. Review of Economics and Statistics $84,353-70$.

-. 2002b. Financial Conditions and Investment during the Transition: Evidence from Czech Firms. In Designing Financial Systems in Transition Economies: Strategies for Reform in Central and Eastern Europe, eds. A. Meyendorff and A. Thakor, 215-60. Cambridge: MIT Press.

Mojon, B.; Smets, F.; and P. Vermeulen. 2002. Investment and Monetary Policy in the Euro Area. Journal of Banking and Finance 26, 2111-29.

Nerlove, M. 2002. Properties of Alternative Estimators of Dynamic Panel Models: An Empirical Analysis of Cross-Country Data for the Study of Economic Growth. In Essays in Panel Data Econometrics, ed. M. Nerlove. Cambridge, UK: Cambridge University Press.

Oliner, S., and G. Rudebush. 1996. Is There a Broad Credit Channel of Monetary Policy?. Federal Reserve Board of San Francisco Economic Review No. 1 (available at www.frbsf.org). 
Peersman, G., and F. Smets. 2005. The Industry Effects of Monetary Policy in Euro Area. The Economic Journal 115, 319-42.

Pruteanu, A. 2004a. Was There Evidence For Credit Rationing in the Czech Republic? Eastern European Economics 42, 58-72.

Pruteanu, A. 2004b. The Role of Banks in the Czech Monetary Policy Transmission Mechanism. Czech National Bank Working Paper Series, No. 3 (available at www.cnb.cz).

Roland, G., and T. Verdier. 2003. Law Enforcement and Transition. European Economic Review 47, 669-85.

Schmitz, B. 2004. What Role Do the Banks Play in Monetary Policy Transmission in EU New Member Countries? University of Bonn. Mimeograph.

Stiglitz, J., and A. Weiss. 1981. Credit Rationing in Markets with Imperfect Information. American Economic Review 71, 393-410.

Vermeulen, P. 2002. Business Fixed Investment: Evidence of a Financial Accelerator in Europe. Oxford Bulletin of Economics and Statistics 64, 213-31. 


\section{Appendix. Construction of Variables}

- $I R_{i t}$ - corporate interest rate for $i$-th firm, $I R_{i t}=I N R E X_{i t} / T D E B T_{i t} . I N R E X_{i t}$ are interest expenses from the profit-loss account, and total debt $\left(T D E B T_{i t}\right)$ is a sum of noncurrent liabilities and bank loans and borrowings from the balance sheet, all for $i$ th firm at time $t$.

- ACCESS $_{\text {it }}$ - market access, measured as 1 minus the ratio of short-term debt to total company debt. Short-term debt is the current liabilities from balance sheets. Total company debt is calculated as the sum of current liabilities, noncurrent liabilities, and bank loans and borrowings from balance sheets. This proxy estimates the extent of short-term financing.

- $\quad D E B T_{i t}-$ net debt of the company.

- $C F_{i t}$ - cash flow, generated by the firm is calculated as the sum of the depreciation of the tangible and the intangible assets and the net income from profit-loss accounts.

- $C O L L_{i t}-$ collateral value of illiquid assets. We first estimate the depreciation rate as follows: DEPRECIATION $_{i t}=\alpha+\beta$ CAPITAL $_{i t}+e$, where DEPRECIATION $N_{i t}$ is a depreciation of tangible and intangible fixed assets from profit-loss accounts, and CAPITAL $_{\text {it }}$ is a sum of tangible and intangible fixed assets from the balance sheets. Having estimated the above equation by the fixed-effects estimator, the results indicate that annual depreciation rate is 8.3 percent (a simple ordinary-least-squares regression yields a value of 8.4 percent). This rate is somewhat higher than findings reported by Lizal (1999). Lizal, using comparable methodology, estimates the annual rate of depreciation between 4.8 and 5 percent. Some of his alternative specifications lead to an estimate of annual depreciation of about 6.3 percent. The data used in Lizal's paper are from the period 1992-95, which may explain the difference in the 
results. Nevertheless, our result is consistent with the Czech accounting standards since the depreciation rate may legally range between 2 and 20 percent. Controlling for industry effects influences the estimated depreciation only minimally. As a result, we work with a depreciation rate of 8 percent when deriving the value of collateral. In this regard, the estimated rate of depreciation is used to compute the collateral value of illiquid assets as: $C O L L_{i, t}=I_{i, t}+(1-\delta) K_{i, t-1}$, where $C O L L_{i, t}$ is the collateral value of illiquid assets in $i$-th firm at time $t, I_{i, t}$ is $i$-th firms' investment at time $t, K_{i, t-1}$ is a booked value of illiquid assets at time $t-1$, and $\delta$ is the rate of depreciation as computed above. As $I_{t}=K_{t}-K_{t-1}$, the value of collateral is computed finally as follows: $C O L L_{i, t}=K_{i, t}-\delta K_{i, t-1}$.

- RECESSION $_{t}$ - dummy. It takes on a value of 1 when GDP y-o-y growth is negative (i.e., 1997 and 1998 in our sample). Analogously, the $B O O M_{t}$ dummy has zero value when y-o-y growth is positive.

- $i_{t} * S_{i}, i_{t} * M_{i}$, and $i_{t} * L_{i}$ - product of the annual average of two-week repurchase rate of the $\mathrm{CNB}$ and dummy variables for small, medium-, and large-sized firms, respectively. The $S_{i}$ dummy takes on a value of 1 when the firm's assets are smaller than the 33 rd percentile of the sample. The $M_{i}$ dummy takes a value of 1 when firm's assets are between the $33^{\text {rd }}$ and $66^{\text {th }}$ percentiles. The $L_{i}$ dummy is 1 when firm's assets lies above $66^{\text {th }}$ percentile.

- $A I R_{t}$ - the weighted aggregate interest rate is used for comparison with the sample corporate interest rates (see Chart 1). The volume of debt outstanding weights the maturity structure of the interest rate for each maturity as follows:

$$
A I R_{i t}=\frac{s t_{i t}}{s t_{i t}+m t_{i t}+l t_{i t}} s i r_{i t}+\frac{m t_{i t}}{s t_{i t}+m t_{i t}+l t_{i t}} m i r_{i t}+\frac{l t_{i t}}{s t_{i t}+m t_{i t}+l t_{i t}} \operatorname{lir}_{i t} \text {, }
$$


where $A I R_{t}$ is representative aggregate interest rate at time $t, s t_{t}$ is the amount of shortterm debt outstanding at time $t, m t_{t}$ is the amount of mid-term debt outstanding at time $t, l t_{t}$ is the amount of long-term debt outstanding at time $t, \operatorname{sir}_{t}$ is short-term average interest rate paid by firms at time $t$, mir $_{t}$ is mid-term average interest rate paid by firms at time $t$, and lir $_{t}$ is the long-term average interest rate paid by firms at time $t$. We use data on the monthly interest rates on loan balances and the monthly statements on loans and receivables from clients, as collected by the Czech National Bank. Shortterm instruments are labeled those with maturities of less than one year, medium-term instruments have maturities between one and five years, and long-term instruments have over five years. The data period is January 1996 to December 2002. 


\section{DAVIDSON INSTITUTE WORKING PAPER SERIES - Most Recent Papers}

The entire Working Paper Series may be downloaded free of charge at: www.wdi.umich.edu

CURRENT AS OF 11/16/06

\begin{tabular}{|c|c|c|}
\hline Publication & Authors & Date \\
\hline $\begin{array}{l}\text { No. 847: Financial Accelerator Effects in the Balance Sheets of Czech } \\
\text { Firms }\end{array}$ & Roman Horváth & Nov 2006 \\
\hline $\begin{array}{l}\text { No. 846: Central Bank Interventions, Communication \& Interest Rate } \\
\text { Policy in Emerging European Economies }\end{array}$ & Balázs Égert & Nov 2006 \\
\hline $\begin{array}{l}\text { No. 845: On the Role of Absorptive Capacity: FDI Matters to } \\
\text { Growth }\end{array}$ & Yuko Kinishita and Chia-Hui Lu & Nov 2006 \\
\hline No. 844: Current Account Sustainability in Selected Transition Countries & Aleksander Aristovnik & Nov 2006 \\
\hline $\begin{array}{l}\text { No. 843: Policy, Economic Federalism \& Product Market Entry: The } \\
\text { Indian Experience }\end{array}$ & $\begin{array}{l}\text { Sumon Bhaumik, Shubhashis } \\
\text { Gangopadhyay and Shagun } \\
\text { Krishnan }\end{array}$ & Nov 2006 \\
\hline No. 842: Price Mobility of Locations & Konstantin Gluschenko & Oct 2006 \\
\hline $\begin{array}{l}\text { No. 841: The Role of Foreign Direct Investment in the Firm Selection } \\
\text { Process in a Host Country: Evidence from Slovenia }\end{array}$ & Katja Zajc Kejzar & Sept 2006 \\
\hline $\begin{array}{l}\text { No. 840: Family Ownership and Control in Large Firms: The Good, The } \\
\text { Bad, The Irrelevant - and Why? }\end{array}$ & Mike Peng and Yi Jiang & Oct 2006 \\
\hline No. 839: Price Linkages of Russian Regional Markets & Konstantin Gluschenko & Sept 2006 \\
\hline $\begin{array}{l}\text { No. 838: The Effect of Pre-Primary Education on Primary School } \\
\text { Performance }\end{array}$ & $\begin{array}{l}\text { Samuel Berlinski, Sebastian } \\
\text { Galiani and Paul Gertler }\end{array}$ & July 2006 \\
\hline $\begin{array}{l}\text { No. 837: Do Investors Value Insider Trading Laws? International } \\
\text { Evidence }\end{array}$ & Laura Beny & Aug 2006 \\
\hline No. 836: How corruption Hits People When They Are Down & Jennifer Hunt & Aug 2006 \\
\hline No. 835: Mirage at the Bottom of the Pyramid & Aneel Karnani & Aug 2006 \\
\hline $\begin{array}{l}\text { No. 834: Ownership concentration and firm performance: Evidence from } \\
\text { an emerging market }\end{array}$ & Irena Grosfeld & June 2006 \\
\hline $\begin{array}{l}\text { No. 833: Institutions, Networks and Entrepreneurship Development in } \\
\text { Russia: An Exploration }\end{array}$ & Ruta Aidis and Saul Estrin & June 2006 \\
\hline $\begin{array}{l}\text { No. 832: Long \& Short Run Linkages in CEE Stock Markets: } \\
\text { Implications for Portfolio Diversification \& Stock Market Integration }\end{array}$ & $\begin{array}{l}\text { Manolis Syllignakis and Georgios } \\
\text { Kouretas }\end{array}$ & July 2006 \\
\hline $\begin{array}{l}\text { No. 831: Inequality, Fiscal Capacity and the Political Regime } \\
\text { Lessons from the Post-Communist Transition }\end{array}$ & $\begin{array}{l}\text { Christopher J. Gerry and Tomasz } \\
\text { Mickiewicz }\end{array}$ & July 2006 \\
\hline $\begin{array}{l}\text { No. 830: Business Groups in Emerging Markets - } \\
\text { Financial Control and Sequential Investment }\end{array}$ & Christa Hainz & June 2006 \\
\hline $\begin{array}{l}\text { No. 829: Sophisticated Discipline in Nascent Deposit Markets: Evidence } \\
\text { from Post-Communist Russia }\end{array}$ & $\begin{array}{l}\text { Alexei Karas, William Pyle and } \\
\text { Koen Schoors }\end{array}$ & June 2006 \\
\hline $\begin{array}{l}\text { No. 828: Financial Deregulation and Financial Development, and } \\
\text { Subsequent Impact on Economic Growth in the CzechRepublic, Hungary } \\
\text { and Poland }\end{array}$ & Patricia McGrath & June 2006 \\
\hline $\begin{array}{l}\text { No. 827: The Determinants \& Excessiveness of Current AccountDeficits } \\
\text { in Eastern Europe \& the Former Soviet Union }\end{array}$ & Aleksander Aristovnik & June 2006 \\
\hline $\begin{array}{l}\text { No. 826: Privatization with Government Control: Evidence from the } \\
\text { Russian Oil Sector }\end{array}$ & $\begin{array}{l}\text { Daniel Berkowitz and Yadviga } \\
\text { Semikolenova }\end{array}$ & $\begin{array}{c}\text { February } \\
2006\end{array}$ \\
\hline No. 825: Corruption \& Bureaucratic Structure in a Developing Economy & John Bennett and Saul Estrin & $\begin{array}{c}\text { February } \\
2006\end{array}$ \\
\hline
\end{tabular}

